\title{
Disaster risk reduction knowledge of local people in Nepal
}

\author{
Gangalal Tuladhar $^{1 *}$, Ryuichi Yatabe ${ }^{2}$, Ranjan Kumar Dahal $^{3}$ and Netra Prakash Bhandary ${ }^{2}$
}

\begin{abstract}
Background: Nepal is highly vulnerable to natural disasters. A high proportion of the national GDP is lost every year in landslides, floods, and many other forms of disasters. A high number of human casualties and loss of public and private property in Nepal due to natural disasters may be attributed to inadequate public awareness, lack of disaster preparedness, weak governance, lack of coordination among the concerned government agencies, inadequate financial resources, and inadequate technical knowledge for mitigating the natural disasters. In this context, quite a few awareness and training programs for disaster risk reduction (DRR) have already been initiated in Nepal and their impact assessments are also already documented. However, effectiveness of the various implemented DRR programs is not yet evaluated through an independent study.

Results: The work presented in this paper explores local people's knowledge on disaster risk reduction (DRR). Altogether, 124 local people from 18 to 74 years of age from randomly selected 19 districts of Nepal were interviewed focusing on various questions on disaster information, disaster knowledge, disaster readiness, disaster awareness, disaster adaptation, and disaster risk perception. The collected response data were statistically analyzed using histogram and independent sample t-tests to examine the DRR knowledge of people. An independent t-test analysis (Table 1) suggests that there is no statistically significant gender-based difference in disaster knowledge, disaster readiness, disaster awareness, and disaster risk perception of the surveyed people. Disaster adaptation capacity of the local people was evaluated and more than 60 percent of the respondents were determined to adapt state of disaster in the community.

Conclusions: Findings of this independent research confirmed that the DRR education initiatives implemented in Nepal are not enough. The questionnaire survey results have pointed out at a few deficiencies in disseminating DRR knowledge in Nepal. We hope these findings will encourage the line agencies working in DRR issues in Nepal to modify their programs targeted for the local communities.
\end{abstract}

Keywords: Disaster knowledge; Disaster risk; Disaster risk reduction; Nepal

\section{Background}

Disaster risk is expressed in terms of potential loss of lives, deterioration of health status and livelihoods, and potential damage to assets and services due to impact of existing natural hazard. Disaster risk reduction (DRR) is a systematic approach to identifying, assessing, and reducing disaster risk, and it helps minimize the vulnerability of a society or community (Maxwell and Buchanan-Smith 1994; Bendimerad F 2003; Kameda 2007; Onstada et al. 2012). It also prevents or mitigates the adverse effects of natural disasters, facilitating a sustainable

\footnotetext{
* Correspondence: gangalaltuladhar@gmail.com

'Himalaya Conservation Group, Kathmandu, Nepal

Full list of author information is available at the end of the article
}

development process. The Second World Conference on Disaster Reduction was held in Kobe (Hyogo), Japan in January 2005, which adopted the Hyogo Framework for Action (HFA) 2005-2015: Building the Resilience of Nations and Communities to Disasters. It has provided a unique opportunity to promote strategic and systematic approach to reducing vulnerabilities and risks. HFA states that all countries must use knowledge, innovation, and education to build a culture of safety and resilience at all levels. Moreover, it suggests that disasters can be reduced substantially if people are well informed and motivated about measures they can take to reduce vulnerability.

Nepal in the Himalayan region is one of the most disaster prone countries in the world. Because of its

\section{Springer}


predominantly steep mountainous terrain in the north and low lying plains in the south, drained by steep and high current rivers originating from the Himalaya, and dominated by strong monsoonal rains, the country is overwhelmed by various natural disasters. The common disasters include landslides, debris flows, floods, earthquakes, snow avalanches, glacial lake outburst floods (GLOF), hailstorms, thunderbolts, cold waves, hot waves, and fire.

Knowingly and unknowingly poverty drives people to go live in high risk marginal areas of mountains and river valleys, which makes them vulnerable to disasters. On the other hand, heavy disaster losses such as during earthquakes and tsunamis or landslides and flood unexpectedly create poverty among a large number of people by destroying their houses, productive lands, other personal assets, and livelihood (Yamin et al. 2005; Takeuchi et al. 2011). Hence, poverty is both cause and consequence of disasters in under-developed or developing countries. Disaster risk reduction is particularly essential for sustaining the achievements of all kinds of development goals since it provides a safety net for the hard-earned development gains of a developing country (Holloway 2003; Birkmann and von Teichman 2010; Walshe and Nunn 2012). In Nepal, it is a great challenge to protect infrastructure and public and individual properties from frequent landslide, flood, and earthquake disasters. Each year hundreds of people are killed and a large amount of public and private properties are destroyed in landslide, flood, fire, and avalanche disasters. Each large-scale disaster potentially sets the country back several years in terms of the development efforts. When scarce resources such as time, energy, expertise, and funding are suddenly diverted in relief and recovery work, the overall development activities are delayed significantly.

The disaster statistics of Nepal always motivate and justify the urgent need of DRR works in Nepal. Therefore, Nepal has also adopted HFA and so far the Government of Nepal (GoN) has assigned the national mandate towards DRR and mainstreaming the DRR in its various development as well as education programs. In Nepal, the World Disaster Reduction Campaign for 2006-2007 was initiated and many programs such amendment in school curricula for disaster risk education, community based disaster management in village level, disaster mitigation plans in district level etc. have been implemented. Similarly, raising awareness within school communities is the well implemented program in the schools of Nepal. This awareness activity include training of teachers; organizing disaster quiz competitions among schools and local youth clubs; school contests on disaster risk reduction knowledge; campaigning for disaster safety in communities; and turning school students into catalysts and initiators in many more community based disaster awareness activities. Results and progress of few disaster risk reduction (DRR) initiatives taken in schools and communities of Nepal were well documented (ActionAid 2011a, b). Recently, Nepal has also started to include disaster risk reduction into secondary and higher education system and curricula.

This article explores the effectiveness of DRR works in the rural communities of Nepal, and examines disaster knowledge of people, disaster preparedness, disaster awareness, disaster adaptation, and disaster risk. It also evaluates the effectiveness of recent DRR programs implemented by various international nongovernmental organizations and national nongovernmental organization (INGOs and NGOs) in the rural communities of Nepal.

\section{Disaster risk and disaster risk reduction initiatives in Nepal}

Natural disasters in Nepal cause a significant impact on the national GDP particularly due to infrastructural damage, destruction of public and private properties, and loss of life. The loss of life and property in particular may be attributed to lack of public awareness, inadequate disaster preparedness, weak governance practice, lack of coordination among the government agencies, inadequate financial resources, and a low level of technical knowhow as well as skill in mitigating natural disasters. In recent years, however, development planners in Nepal seem to have understood the intimate link between the disasters and development strategies. In average, per day at least two people die in Nepal due to natural disasters (MoHA Ministry of Home Affairs et al. 2008). A record of loss of human lives in various types of disasters in Nepal in the last 25 years (1986- 2011) is shown in Figure 1 (MoHA Ministry of Home Affairs 2003; DWIDP Department of Water Induced Disaster Prevention 2006; MoHA Ministry of Home Affairs et al. 2009). The data are evident how severely the country has suffered from the natural disasters in the last two and half decades (1986-2011). In landslides and floods, the human casualty reaches as high as 288 per year. An existing data record in South Asia shows that Nepal stands third in annual average human deaths per million living population after Sri Lanka and Bangladesh.

These disaster statistics have always motivated and justified an urgent need of DRR works in Nepal. Therefore, Nepal is one of the 168 countries that have adopted the HFA. So far, the Government of Nepal (GoN) has assigned a national mandate towards disaster risk reduction and its mainstreaming through various programs.

Following the HFA strategies, various international nongovernmental organizations working in the field of DRR have begun some ambitious programs designed to reduce people's vulnerability to natural disasters and build a stronger base of community-based disaster education. In Nepal too, especially after 2006 many programs have been introduced and implemented by various government and nongovernment agencies. A 


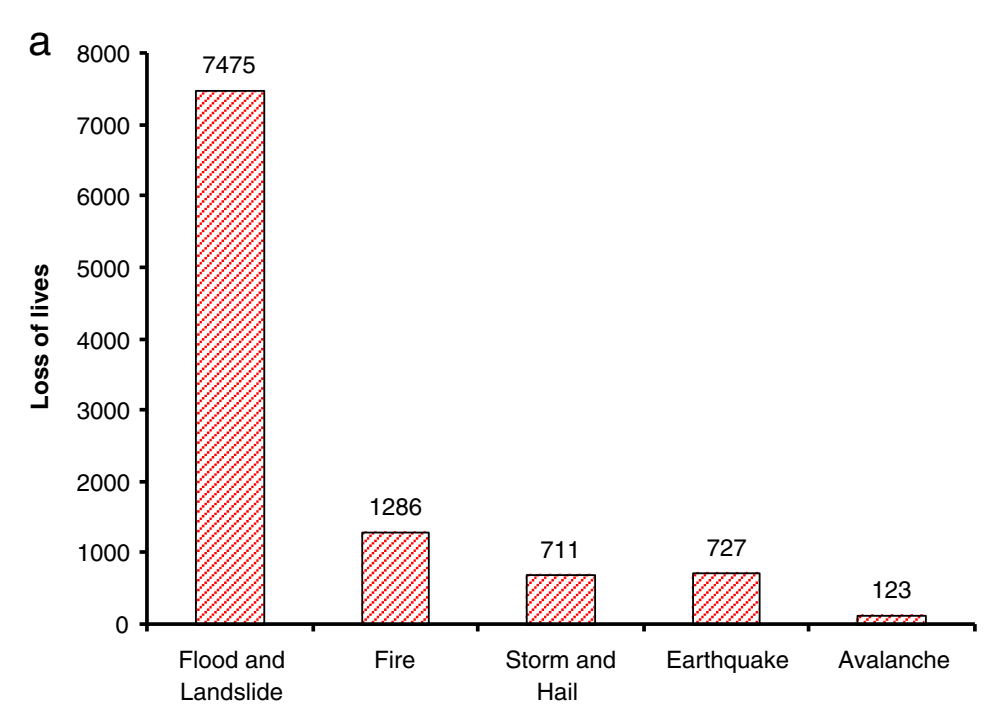

Type of disasters

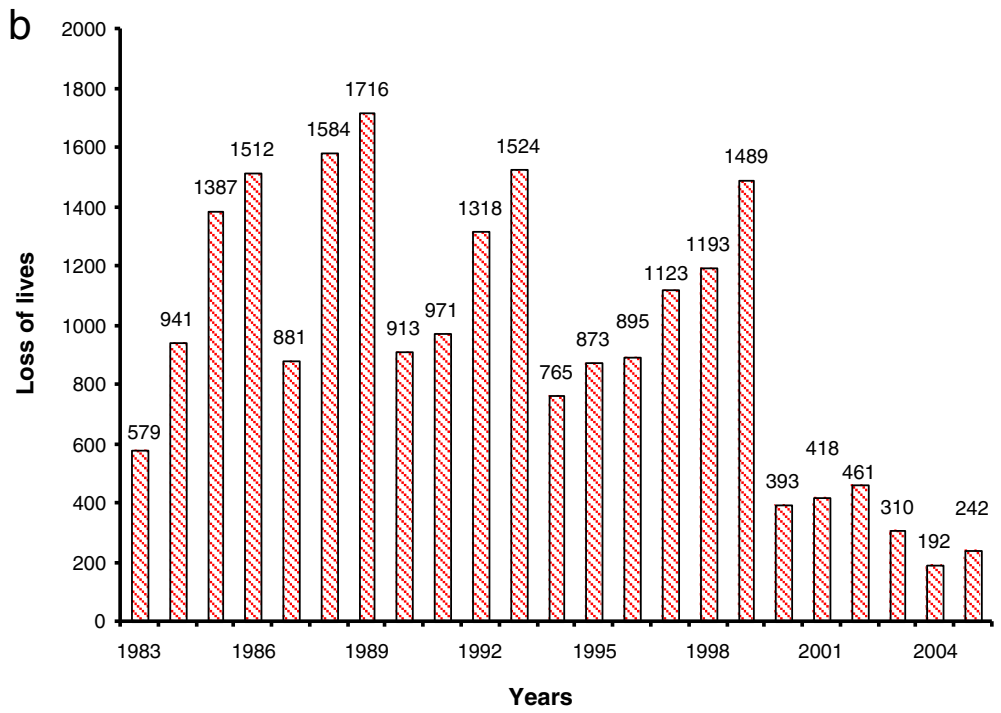

Figure 1 Loss of lives due to various disasters in Nepal between 1986 and 2005 (a), and number of deaths due to disasters in Nepal from 1983 to 2005 (b). Source: MoHA (2003), DWIDP (2006), MoHA et al. (2009).

little change has also been made in the school-level curricula. Many disaster education-related programs have also been initiated (Figure 2) by both governmental and nongovernmental organizations (NGOs) (ActionAid 2011a, 2011b; UNESCO United Nations Educational, Scientific and Cultural Organization and UNICEF United Nations Children's Fund 2012; MercyCorp 2013) in community levels.

Raising DRR awareness level among the communities is one of the well-implemented programs in Nepal. The activities include teachers' trainings, disaster quiz competitions, youth club activities on DRR knowledge, disaster safety campaigns, and disaster drills. Establishing a sense of prevention in communities is another widely practiced DRR initiative in Nepal. For this, NGOs are involved in developing disaster education materials, coordinating for mainstreaming disaster risk reduction in national education system, and teaching youths, leaders, and parents the disaster risk reduction issues. Building earthquake safe communities and retrofitting existing structures are other areas of interest for the NGOs in Nepal towards building a disaster safe society. In this program, the government and NGOs are involved in assessing the vulnerability of school facilities, retrofitting school buildings, building earthquake-resistant schools, relocating schools in high disaster risk areas, and building new schools in low disaster risk areas. Results and progress of a few disaster risk reduction (DRR) initiatives 


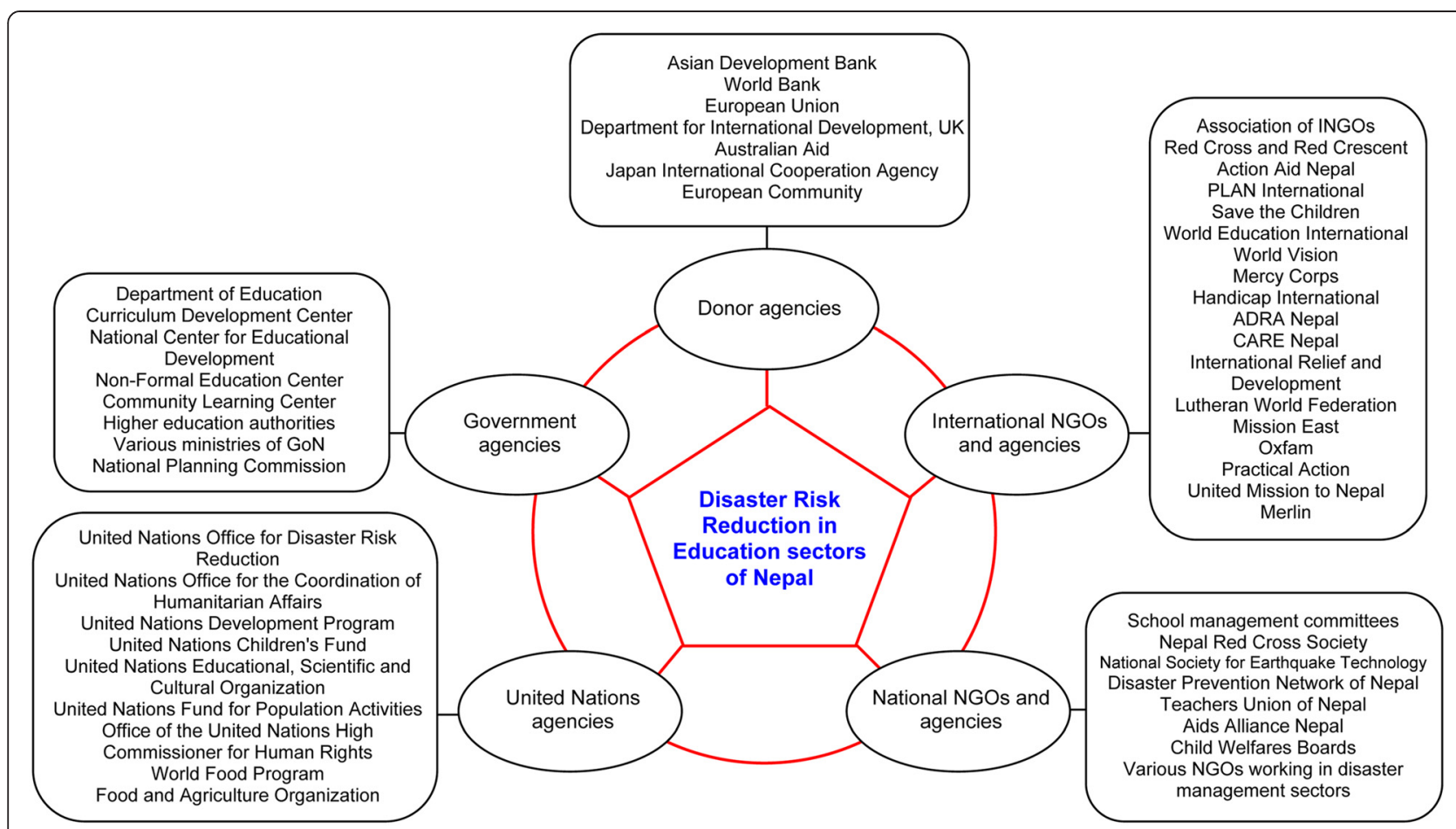

Figure 2 Framework for disaster risk reduction initiative in education sectors and implementation plan of Government of Nepal.

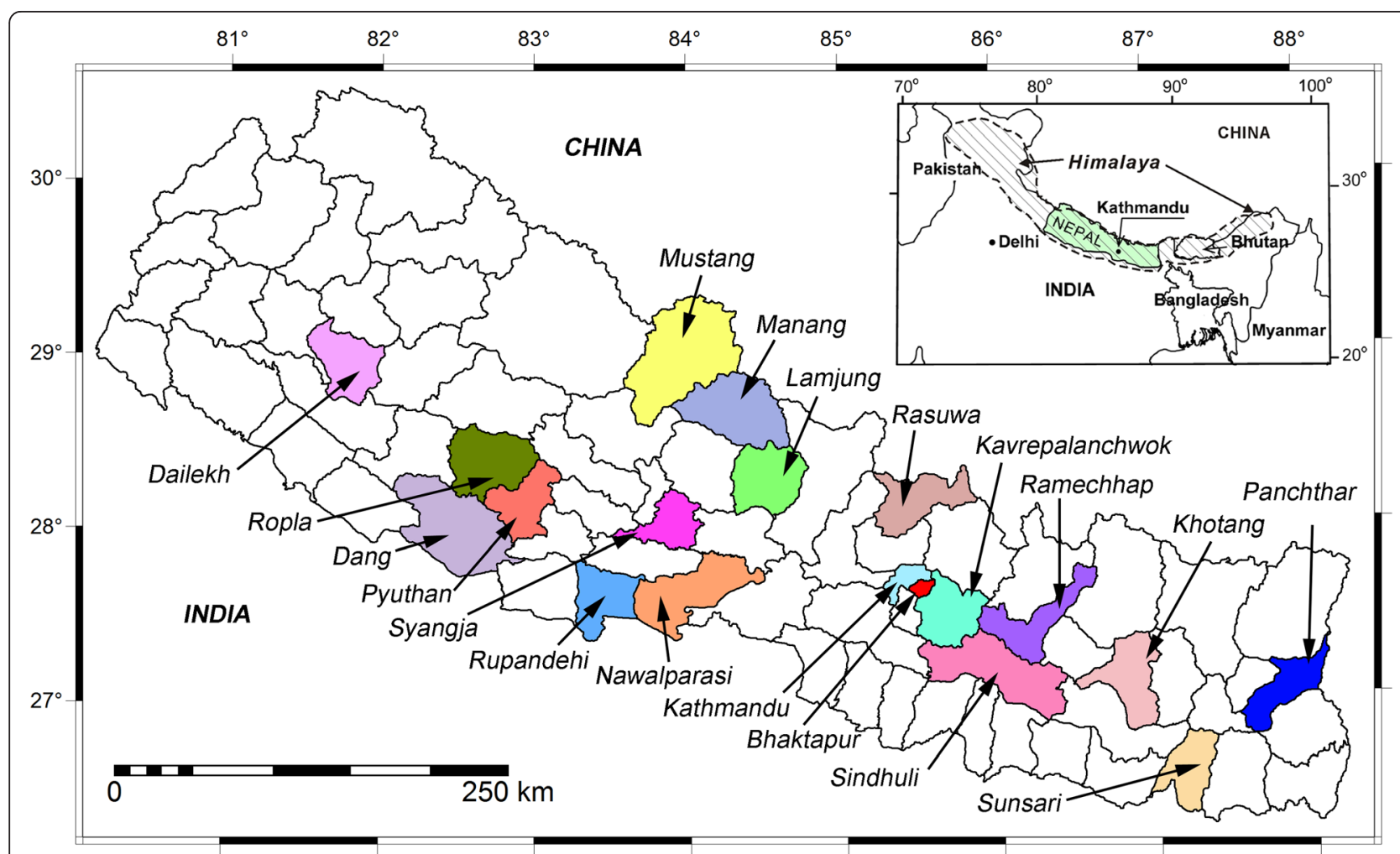

Figure 3 Location of 19 sample districts where randomly selected local people were interviewed. 
taken in the schools of Nepal are well documented (Shiwaku et al. 2007; ActionAid 2011a, 2011b), and DRR has already been incorporated in the education system and school curricula (UNESCO United Nations Educational, Scientific and Cultural Organization and UNICEF United Nations Children's Fund 2012).

\section{Methods}

This study was intended to explore the level of DRR knowledge in local people and to examine the effect of DRR programs in Nepal on a number of aspects including risk perception, knowledge on available safety system in an event of disaster, preparedness of families and communities, and available disaster adaptation process up until now. The study also explores effectiveness of DRR implemented by various international nongovernmental organizations and national nongovernmental organization (INGOs and NGOs) in the rural communities of Nepal.

\section{Data collection}

For this study, 19 districts of Nepal (out of 75) were randomly selected as sampling districts. During random selection, geographical distribution, development index and DRM activities of both government and nongovernment organization of each district were taken into consideration. The surveyed districts are shown in Figure 3. Also considered in the survey were activities of nongovernmental organizations in each district, disaster history (Aryal 2012), rainfall-related disasters (Dahal and Hasegawa 2008), and recent earthquake disaster (Dahal et al. 2012). The study was conducted in assumptions that the local people are now gaining DRR knowledge through various trainings, awareness campaigns, and workshop programs organized by both national and international nongovernmental organization (ActionAid 2011a, b, UNESCO United Nations Educational, Scientific and Cultural Organization and UNICEF United Nations Children's Fund 2012). For the survey, a questionnaire sheet was prepared and a total of 124 local people (participants) from the randomly selected districts were asked to respond to the questions. The respondents consist of 15 percent female and 85 percent male with an age range of 18 to 74 years and mean of 38 years $(S D=11.8)$. Only 18 years (youths) or older from a variety of socioeconomic and cultural backgrounds were considered for the interview.

The questionnaire survey criteria used in this study were adopted from the suggestions made in the available books and literatures (Kuroiwa 1993; McMillan and Schumacher 1993; Andrews et al. 1998; Thorne 2000; Henning et al. 2004; Tanaka 2005; Ronan et al. 2010; Lekalakala 2011), and they were embedded together within a single survey sheet.
Questions about various natural disasters were asked to assess the level of people's knowledge about these disasters. The participants' knowledge level was evaluated in terms of their understanding about the occurrence of floods, landslides, earthquakes, fires, high winds, hailstorm, drought, and extreme rainfall in five levels: (1) Never, (2) Rarely, (3) Sometimes, (4) Often, and (5) Always.

In addition, the survey participants were asked two sets of questions related to their feelings over the disaster and various issues of disaster management. . Major question "What are your feelings over the disaster?" was asked in the form of 9 statements. Similarly, 18 statements were asked to respond for another set of major question "What do you think about the following issues (18 statements) for disaster management". They were asked to indicate their responses in various statements (included in the two major question sets as most probable answers) in five levels: (1) Strongly disagree, (2) Disagree, (3) Agree, (4) Strongly agree, and (5) I do not know. Later in the analysis phase, the statements were categorized into five groups to explore knowledge of respondents on DRR as (i) Disaster-related knowledge, (ii) Disaster preparedness and readiness, (iiii) Disaster adaptation, (iv) Disaster awareness, (v) Disaster risk perception. A summary of the statements incorporated in the questionnaire survey is as follows.

Disaster-related knowledge

$\square$ I know when a disaster will occur

$\square$ I know disasters cannot be prevented

$\square$ I have participated in disaster risk education training or workshop

Disaster preparedness and readiness

$\square$ I think to come across a disaster and remain alive depends on our luck

$\square$ I know importance of disseminating experiences or knowledge of disaster

$\square$ I know government will provide enough facilities after disaster and we will not face any problem

$\square$ I am confident for reconstruction activities from government after disaster

$\square$ I know the importance of talking about disasters with neighbours, friends and colleagues

$\square$ I used to listen experts or DRR leaders who work or do activities for disaster management

Disaster adaptation

$\square$ I am aware of the shelter areas and open space in case of a disaster

$\square$ I have information about which government office needs to be contacted after the disaster 
$\square$ I have knowledge about disaster prone area

$\square$ I am getting enough information from INGO/NGO about disaster adaptation

$\square$ I have knowledge about an evacuation area during a disaster

$\square$ I know the important of community activities for disasters risk reduction

$\square$ I know the life evacuation system in my locality

\section{Disaster awareness}

$\square$ I used to participate in voluntary activities for disaster awareness campaigns

$\square$ I am aware of retrofitting of buildings

$\square$ I used to prepare emergency bag for disasters

$\square$ I have a good relationship with my neighbours and community

$\square$ I think repair of road blockage and transportation break are important

$\square$ I give priority to disaster awareness in local, regional and national level

$\square$ I know recovery after disaster is a crucial work

Disaster risk perception

$\square$ I am very sure that large-scale disasters will certainly occur in next 10 years

$\square$ My locality is safe from all kinds of disasters

$\square$ I think my building is well designed and will withstand an earthquake event

$\square \mathrm{I}$ am sure that my sleeping space is secure during and after disaster

\section{Survey procedure}

Local representatives of the major political parties in Nepal, who have basic knowledge of disasters, were selected as enumerators, as they usually have a close acquaintance and a strong convincing relation with the local people. The enumerators were asked to select survey participants with basic education (that is, at least high school graduates) who could understand and answer the questions well. The survey was conducted more in presence of the enumerators themselves in an interview style for the clarity of the questions as well as answers of the respondents. In average, total time required for completing one survey was 20-30 minutes.

\section{Method of analysis}

To examine overall DRR knowledge of local people, histogram analysis, bivariate correlations and independent sample t-tests was conducted. Basically, the descriptive analyses helped to examine the relationship between disaster risk reduction initiatives of government of Nepal and the local people's knowledge on DRR. Five key DRR issues were considered in our analysis: disaster knowledge, disaster readiness, disaster awareness, disaster adaptation, and disaster risk perception. Responses in these key issues were also evaluated with histogram analyses. A series of independent sample t-tests were also conducted to examine the effects of gender and disaster events. For this purpose, the five responses (Strongly disagree, Disagree, Agree, Strongly agree, and I do not know) were rephrased. For example, if a respondent responded strongly agree for all five DRR issues, it was considered that he/she well understood of the disaster knowledge, he/she was very ready to tackle the state of disaster, he/she is well aware for disaster risks, he/she can well adapt state of disaster and he/she is well perceived disaster risk. Similarly, if a respondent responded strongly disagree for all five DRR issues; it was considered that he/she has no idea of the disaster knowledge, disaster readiness, disaster awareness, disaster adaptation and disaster risk perception.

\section{Results}

As mentioned in methodology, basically three kinds of analyses have been done to explore overall DRR knowledge of local people in Nepal. The effects of gender and disaster events were evaluated with independent sample t-tests and bivariate correlations. People's knowledge on DRR issues in Nepal was evaluated with histogram analyses. Disaster insecurity of local people was also evaluated from histogram plot. Results of analysis are given in the following headings.

\section{Gender effects on disaster risk reduction issues}

Demographic factors always have some relationship with DRR process in a community. To explore this issue, preliminary analysis has been carried out on the basis of gender and age groups of the local people.

An independent t-test analysis (Table 1) suggests that there is no statistically significant gender-based difference in disaster knowledge, disaster readiness, disaster awareness, and disaster risk perception of the surveyed people, which can be understood from significance of t-test values greater than 0.05 (two-tailed) for almost all key disaster issues. Only for the case of awareness, the male participants were found more confused than the female, as indicated by less than 0.05 significance of $t$-test result.

Likewise, when the people were asked about the use of media as a source of disaster information, it was found that the number of females using national television (that is, Nepal Television) is greater, but the males were found to prefer FM radios to learn about and get disaster information.

\section{Disaster risk reduction issues and People's response}

The DRR knowledge of local people was analyzed with people's response on five key DRR issues (disaster 
Table 1 Statistical analysis of key disaster risk reduction issues

\begin{tabular}{|c|c|c|c|c|c|c|c|}
\hline \multirow{2}{*}{\multicolumn{2}{|c|}{ Key DRR Issues }} & \multicolumn{2}{|c|}{ Female } & \multicolumn{2}{|l|}{ Male } & \multirow[t]{2}{*}{$t(124)$} & \multirow[t]{2}{*}{ Sig. } \\
\hline & & Mean & SD & Mean & SD & & \\
\hline \multirow[t]{5}{*}{1} & $\begin{array}{l}\text { Knowledge: Well } \\
\text { understood }\end{array}$ & 42.33 & 10.50 & 33.67 & 5.51 & 1.27 & 0.27 \\
\hline & $\begin{array}{l}\text { Knowledge: } \\
\text { Understood }\end{array}$ & 35.00 & 8.19 & 3 & 79 & 9 & 5 \\
\hline & Knowledge: Not clear & 16.00 & 5.00 & 1 & 4.62 & 1.10 & 0.33 \\
\hline & Knowledge: Confusing & 5.33 & 5.51 & 7.00 & 0.00 & -0.52 & 0.63 \\
\hline & Know & 1.67 & 2.89 & 4.33 & 1.53 & -1. & 0.23 \\
\hline \multirow[t]{5}{*}{2} & Readiness: Very ready & 24.86 & 15.53 & 25.14 & 17.35 & -0.03 & 0.97 \\
\hline & Readir & 4 & 15.74 & 32.57 & 16. & 0 & 0.46 \\
\hline & Readiness: Not ready & 24.14 & 21.61 & 21.29 & 11.61 & 0.31 & 0.76 \\
\hline & Readiness: Confusing & 7.71 & 4.42 & 12.29 & 10.29 & -1.08 & 0.30 \\
\hline & ss: No idea & 4.43 & 7.68 & 8.57 & 5.94 & -1.13 & 0.28 \\
\hline \multirow[t]{5}{*}{3} & Awareness: Well aware & 21.71 & 13.56 & 21.71 & 11.76 & 0.00 & 1.00 \\
\hline & Aware & 42.00 & 10.50 & 42.43 & 5.80 & -0.09 & 0.93 \\
\hline & Awareness: Not aware & 22.71 & 10.34 & 16.14 & 5.90 & 1.46 & 0.17 \\
\hline & Awa & 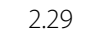 & 77 & 7.29 & 1.80 & 2. & 0 \\
\hline & Awareness: No idea & 11.43 & 4.93 & 13.14 & 7.52 & -0.50 & 0.62 \\
\hline \multirow[t]{5}{*}{4} & $\begin{array}{l}\text { Adaptation: Well } \\
\text { adapted }\end{array}$ & 32.29 & 13.21 & 29.57 & 11.16 & 2.71 & 0.69 \\
\hline & Adaptation: & 7 & 25 & 4 & 7.63 & -0. & 0 \\
\hline & $\begin{array}{l}\text { Adaptations: Not } \\
\text { adapted }\end{array}$ & 14.29 & 7.87 & 11.14 & 3.76 & 3.14 & 0.36 \\
\hline & Adaptation: Confusing & 7.57 & 5.35 & 6.29 & 2.36 & 1.29 & 0.57 \\
\hline & Adaptation: No idea & 8.43 & 7.44 & 10.00 & 4.55 & -1.57 & 0.64 \\
\hline \multirow[t]{5}{*}{5} & $\begin{array}{l}\text { Perception: Well } \\
\text { perceived }\end{array}$ & 14.8 & 15.7 & 18.3 & 20.5 & -0.582 & 0.582 \\
\hline & Perception: Perceived & 9.0 & 11.6 & 14.3 & 8.5 & -0.154 & 0.883 \\
\hline & $\begin{array}{l}\text { Perception: Not } \\
\text { perceived }\end{array}$ & 44.8 & 20.3 & 28.8 & 18.0 & 1.18 & 0.283 \\
\hline & Perception: Confusing & 22.5 & 17.0 & 24.0 & 9.5 & -0.73 & 0.493 \\
\hline & Perception: No idea & 9.3 & 15.3 & 15.5 & 15.0 & -0.271 & 0.796 \\
\hline
\end{tabular}

knowledge, disaster readiness, disaster awareness, disaster adaptation and disaster risk perception) considered in this research. Results for each issue are described in following sub-headings.

\section{Disaster-related knowledge}

Three main questions were asked to explore the level of disaster-related knowledge. More than 30 percent of the respondents were found to be familiar with the disaster-related facts (Figure 4). About 80 percent of them were found to agree with the importance of disaster riskrelated trainings for them. This result indicates that the awareness campaigns of both governmental and nongovernmental organizations related to disaster knowledge in local level are in satisfactory level, and the people are rather positive about gaining disaster-related knowledge.

\section{Disaster preparedness and readiness behaviour}

Six main questions were asked to explore people's readiness behaviour towards the disasters. Out of these questions, there were positive responses for five questions and negative responses for two questions. More than 80 percent respondents do not think that the government has made enough preparations for DRR (Figure 5). They also do not agree that the government provides enough relief after a disaster. They also comment that there is a lack of governmental mechanism to support them after a disaster. About 25 percent respondents still believe that disaster and loss have direct link with their fate, while about 70 percent of the respondents are not convinced that governmental or nongovernmental institutions will initiate the post-disaster reconstruction activities. However, the respondents were found to be well motivated to talk about the disasters with their friends, colleagues, and neighbors. An overall impression about the readiness behavior of the people suggested that nearly 25 percent of the local people are still confused and are not ready to confront the disasters.

\section{Disaster adaptation}

The disaster adaptation capacity in the local people of Nepal was evaluated through seven main questions (Figure 6). In general, more than 60 percent of the respondents were determined to adapt state of disaster in the community. At present, although DRR programs and campaigns are being implemented and accomplished by various INGOs and NGOs, nearly 50 percent of the respondents was found negative on their activities, and respondents give little importance to the role of INGOs/NGOs in disaster information dissemination.

\section{Disaster awareness}

Seven statements were asked to evaluate respondent's disaster awareness level (Figure 7). Only less than 20 percent of them were confused with the awareness activities for disaster risk in their community. This is a positive result for the governmental or nongovernmental institutions that are working for DRR issues in the community level. However, nearly 20 percent of respondents do not know or do not agree with the concept of disaster emergency bag. They emphasized that the concept of emergency bag is not practical for them.

\section{Disaster risk perception}

Four main questions were asked to the respondents so as to evaluate the risk perception. More than 75 percent of the respondents were found to be unaware of large-scale disasters in their communities (Figure 8) despite the fact 


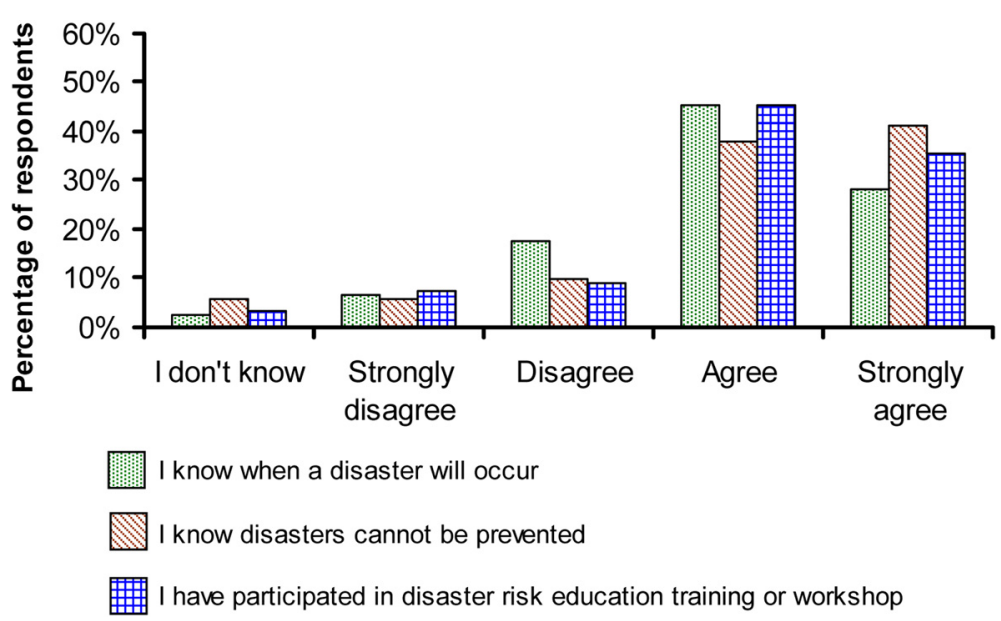

Figure 4 Evaluation of disaster-related knowledge in local people of Nepal.

that the annual disaster record of Nepal (see Figure 1) roughly indicates that major disasters occur in about every 10 years.

\section{Disaster insecurity}

People were asked about the level of insecurity they have from eight kinds of common natural disasters in Nepal. They responded in five levels of insecurity from the disasters. The responses clearly demonstrate their disaster risk perception. Most of the respondents feel that they are insecure from all kinds of disasters (Figure 9), but the maximum insecurity is associated with earthquake, storm, hail, drought, and extreme rainfall. Nearly 40 percent of the respondents feel that landslides may not be a problem for them, which in fact is a highly underestimated response. As most of the respondents are from mountainous areas, they must have a sound knowledge of landslide processes and associated disasters in their area. In case of floods also, the respondents were found to have a similar opinion. This clearly indicates that the DRR issues are either not being well protruded or are focused more on earthquake issues in the community level. Although many people are well aware disaster awareness programs, still one third of the respondents were worried for all kind of disasters and could not recognize major disaster problem in his/her area.

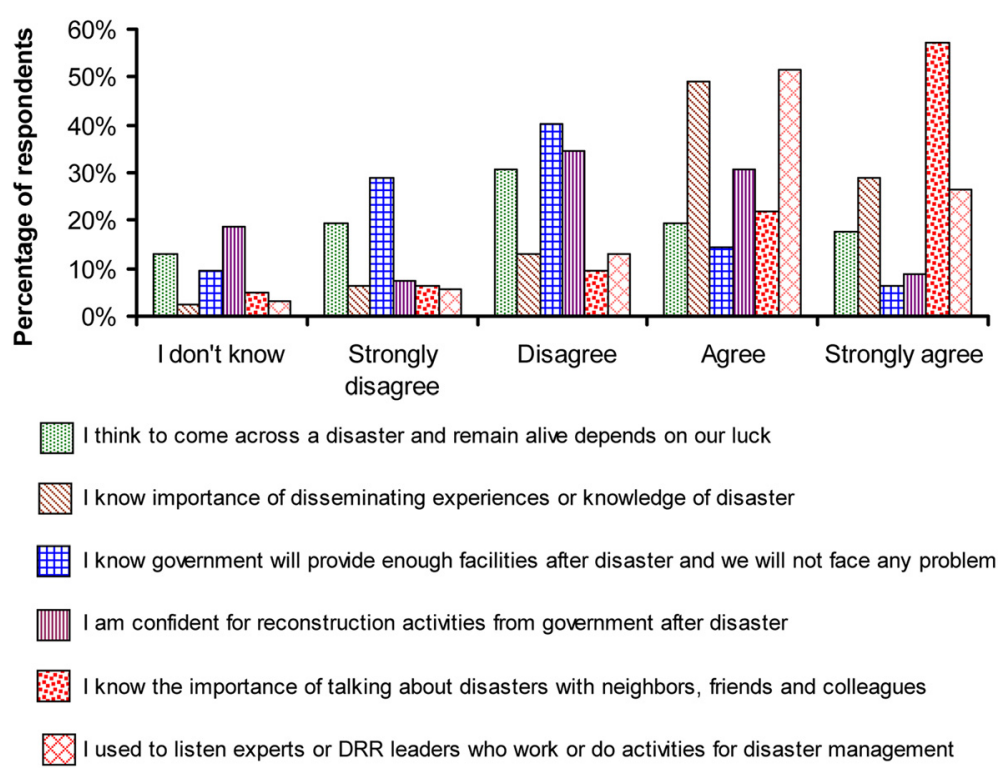

Figure 5 Readiness behaviour of people for disaster risk reduction. 


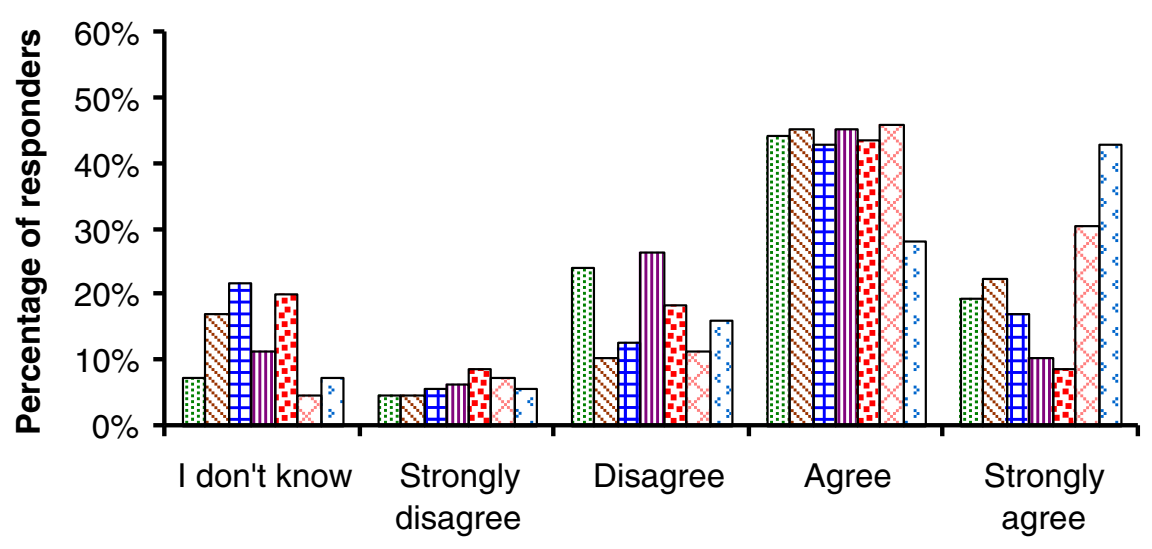

監 Aware of the shelter areas and open space in case of a disaster

Information about which government office needs to be contacted after the disaster

囲 Knowledge about disaster prone area

Getting enough information from INGO/NGO about disaster adaptation

Knowledge about an evacuation area during a disaster

$\bigotimes$ Community activities for disasters

Life in state of evacuation after the disaster

Figure 6 Response of the people to the various disaster adaptation systems in the community.

\section{Discussion}

This study has helped to understand the status and importance of DRR knowledge dissemination process in rural communities of Nepal. Although the line agencies (that, governmental and nongovernmental institutions that have been involved in DRR activities in various communities of Nepal) claim that DRR concept and disaster education are now already functioning in the local communities and all local people have been gaining DRR knowledge through awareness campaigns, trainings, meetings, and so on, the ground reality indicates that the situation is still incoherent. In this work, people's knowledge in five key DRR issues was explored through a questionnaire survey on at least high school graduates, but the findings are not very encouraging. For example, one of findings indicates that many people are still obscured on awareness activities for disaster risk management in community. A few satisfactory results were obtained particularly concerning the status of people's knowledge in disaster. Although the level of knowledge of both male and female respondents in DRR issues is not different, many males were found to be still confused about procedures for raising disaster awareness. An analysis of the obtained results has shown that the local people lack accurate knowledge of disasters and their mitigation. Despite a fact that landslides and flood are most affecting and most frequent natural disasters in Nepal, many people were found to feel only less insecure from these disaster events. In Nepal, for the last 20 years, the information about earthquake disaster is well disseminated by various organizations (Dixit et al. 2013), which might have resulted in positive consequences of people's increased awareness in earthquake-related disasters. Moreover, despite a fact that disaster education programs are doing good or satisfactory in Nepal (UNESCO United Nations Educational, Scientific and Cultural Organization and UNICEF United Nations Children's Fund 2012), the survey results have shown that the people have a greater likelihood of feeling insecure about all kinds of disaster. Even today, most people do not have site-specific disaster knowledge, and the level of anxiety towards all kinds of disasters is the same. More than 30 percent of the respondents have answered that all of the eight kinds of disasters (flood, landslide, earthquake, fire, storm, hail, drought, and extreme rainfall) may occur sometime in their areas, which in fact is not a correct understanding of major disaster issues of his/her area.

Although the number of samples collected is not high, this study has pointed out a few deficiencies in 


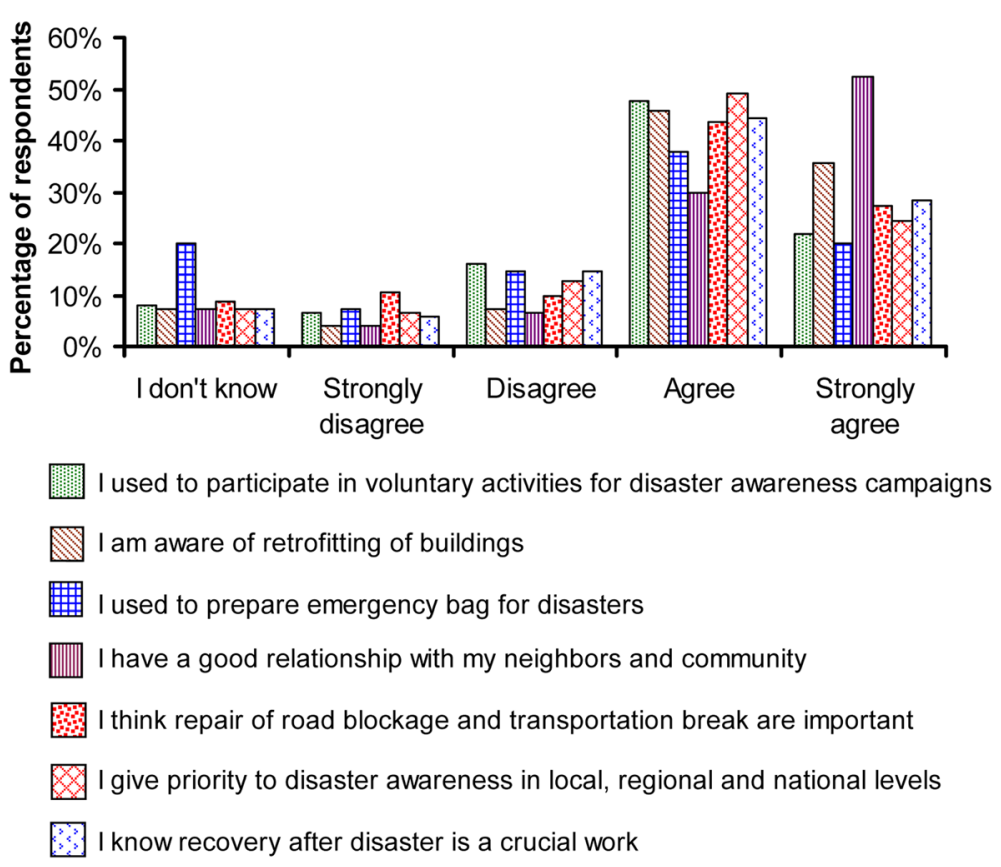

Figure 7 Response of the people to various disaster awareness related action in the community.

the process of disseminating disaster risk reduction knowledge in Nepal. The findings in this work are expected to encourage the line agencies that have been working in DRR issues in the country towards modification in their programs intended for the local communities. We believe an independent research work, such the one done in this study, more clearly shows the overall status of people's knowledge as well as understanding in any relevant fields including DRR.

\section{Conclusions}

The questionnaire survey results obtained during the course of this field-based research work clearly point out at the deficiencies and limitations in the process of DRR knowledge dissemination to the local communities of Nepal. This work has attempted to evaluate specific outcomes in relation to disaster preparedness of the local people, their ability to identify and address the risk of disasters, and disaster adaptation practice. However, in many DRR issues, people are still not

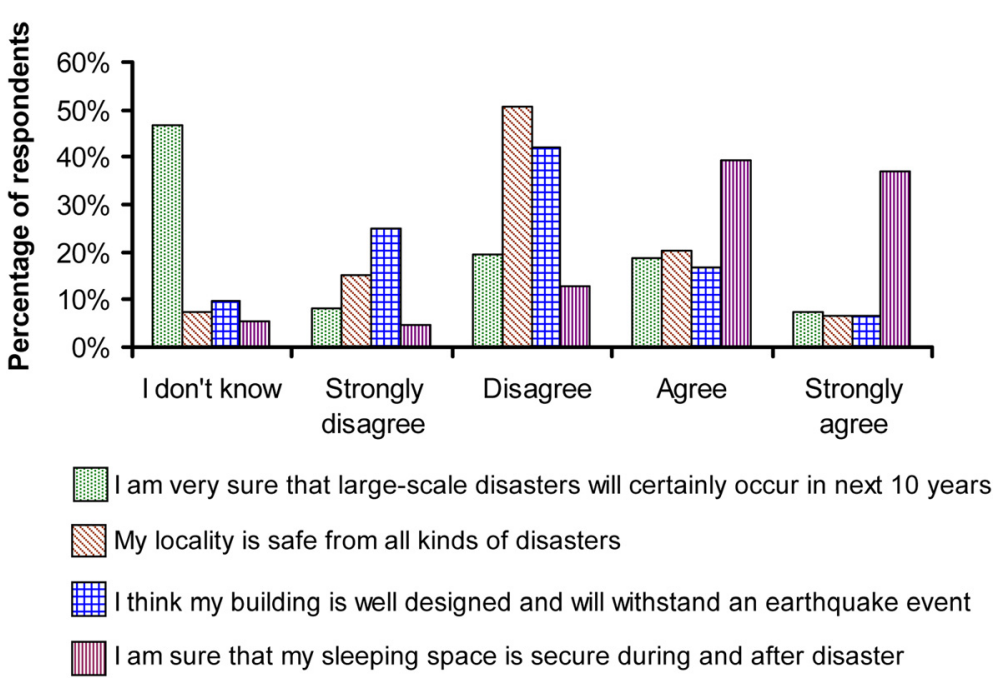

Figure 8 Evaluation of risk perception of the people in the community. 


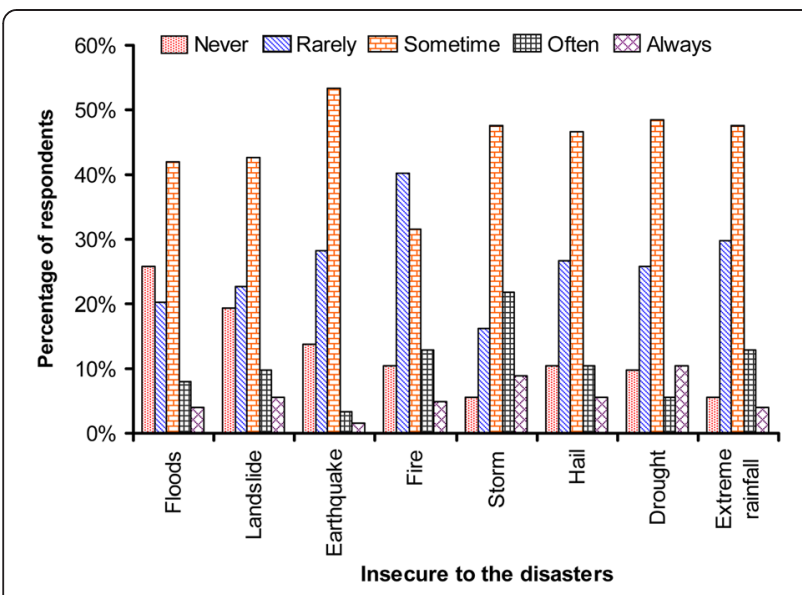

Figure 9 Level of anxiety from different kind of disasters in Nepal.

very clear and at the same time, they respond incorrectly. Likewise, she/he is well aware for disaster risks but she/he is not well familiar with the adapt state of disaster. This is a contradictory response obtained during survey. Through this study, it is understood that there are many DRR lessons the local people need to learn further, and that the existing DRR knowledge dissemination programs and processes need to be revised. Despite also having the Hyogo Framework for Action 2005-2015 (UNISDR United Nations International Strategy for Disaster Reduction 2004, 2007, 2011) adopted, the survey results show that Nepal has not satisfactorily implemented the DRR education initiatives. The HFA well emphasizes the role of education in DRR, especially the need of disaster education for developing a culture of disaster prevention in communities and schools.

At the present political and social conditions, the disaster risk reduction programs run particularly by the INGOs or NGOs may sometimes also be misleading. As an important tributary of a broader sustainable development pathway, DRR must be integrated with the development process in the communities. It needs to be mixed up with the development process at different stages, and must become an integral part of the development activities. In DRR process, culture of safety can also be easily introduced if the communities are adequately educated, equipped, and resourceful through good governance. In reality, the existing DRR programs in Nepal are rich in jargons and they cannot be simply or easily implemented in communities. Through this study, we have clearly understood that people are not adequately aware even of simple disaster issues, and that in some cases, they are over reckoning too. In general, people need information that leads to action, for example, what they should do on their own today or tomorrow and who they should consult for any additional support. Another tragedy about DRR in Nepal is that its practice is badly overshadowed and blended into various hypothetical approaches; and to the worst, most of the resources are spent more in discussions, workshops, and hiring foreign consultants instead of taking immediate action in the field with whatsoever available indigenous knowledge. As a result, DRR mainstreaming programs are likely to fade out between the communities and the line agencies leading to a dilemma of DRR knowledge among the local communities.

One of the major challenges in DRR practice in a rural country like Nepal is implementation method, especially at personal level. The method of disaster education provides people knowledge and information and promotes the DRR measures. To achieve this, local people need to be encouraged to learn about disaster basics, readiness behavior, awareness programs, adaptation process, and risk identification techniques. To strengthen people's disaster risk awareness, proper and appropriate information should be disseminated to the local community leaders. Disaster education-related campaigns and programs may also provide a self-learning environment to the local people. School disaster education programs should also be encouraged in such a way that the community people can participate in the school disaster education program and the students can participate in community-based disaster awareness and adaptation activities. These activities may help increase the knowledge of DRR in the communities, which may lead the community and people to greater readiness for disaster risk reduction process.

\section{Competing interest}

The author's declare that they have no competing interest.

\section{Author's contribution}

GT collected the data and performed the statistical analysis. He also drafted the manuscript. RY, RKD and NPB give suggestions on methodology and developing questionnaire. All four authors read and approved the final manuscript.

\section{Acknowledgment}

This research has been conducted with the extensive help from officials and staffs of Himalayan Conservation Group. Local political leaders are also acknowledged for their heartfelt support in data collection.

\section{Author details}

${ }^{1}$ Himalaya Conservation Group, Kathmandu, Nepal. ${ }^{2}$ Department of Civil and Environmental Engineering, Graduate School of Science and Engineering, Ehime University, Matsuyama 790-8577, Japan. ${ }^{3}$ Department of Geology, Trichandra Campus, Tribhuvan University, Tribhuvan, Nepal.

Received: 7 October 2014 Accepted: 5 December 2014 Published online: 26 February 2015

\section{References}

ActionAid. Disaster Risk Reduction through Schools: Learning from our experience 5 years on. 2011 a. http://www.actionaid.org/sites/files/actionaid/ drrs_final_report_to_dfid.pdf. Accessed on June 2013. 
ActionAid. Disaster Risk Reduction through Schools: A Groundbreaking Project. 2011 b. http://www.actionaid.org/sites/files/actionaid/ disaster_risk_reduction_through_schools.pdf. Accessed on June 2013.

Andrews J, Benthien M, Tekula S (1998) Southern California Earthquake Center Outreach Report 1998: Public Awareness, Education and Knowledge Transfer Programs and Fiscal Year 1998 Activities. http://www.scec.org/research/ 98research/98andrews.pdf. Accessed on May 2012.

Arya AS. Training and drills for the general public in emergency response to a major earthquake. In: Training and Education for Improving Earthquake Disaster Management in Developing Countries, Report and Summary of Proceedings of the Sixth International Research and Training Seminar on Regional Development Planning for Disaster Prevention, Tsukuba, Japan, 14 December 1992, Nagoya, Japan. UNCRD Meeting Report Series, No. 57. Nagoya, Japan: United Nations Centre for Regional Development; 1993. p. 103-14. http://www.virtualref.com/uncrd/1563.htm.

Aryal KR. The History of Disaster Incidents and Impacts in Nepal, 1900-2005. Int J Disaster Risk Sci. 2012;3(3):147-54.

Bendimerad F (2003) Disaster Risk Reduction and Sustainable Development. World Bank Seminar on The Role of Local Governments in Reducing the Risk of Disasters, Held in Istanbul, Turkey, 28 April-2 May 2003, 57-75. http://info. worldbank.org/etools/docs/library/114715/istanbul03/docs/istanbul03/ 05bendimerad3-n[1].pdf. Accessed on May 2013.

Birkmann J, von Teichman K. Integrating disaster risk reduction and climate change adaptation: key challenges - scales, knowledge, and norms. Sustainability Sci. 2010;5(2):171-84.

Dahal RK, Hasegawa S. Representative rainfall thresholds for landslides in the Nepal Himalaya. Geomorphology. 2008;100(3-4):429-43.

Dahal RK, Bhandary NP, Yatabe R, Timilsina M, Hasegawa S. Earthquake-Induced landslide in the roadside slopes of east Nepal after recent September 18, 2011 earthquake. In: Ugai K, Yagi H, Wakai A, editors. Earthquake-Induced Landslides. Berlin: Springer-Verlag; 2012. p. 149-57.

Dixit AM, Yatabe R, Dahal RK, Bhandary NP. Initiatives for earthquake disaster risk management in the Kathmandu Valley. Nat Hazards. 2013;69(1):631-54.

DWIDP (Department of Water Induced Disaster Prevention) (2006) Disaster Review 2006, http://www.dwidp.gov.np/uploads/document/file/ review_20120213035717.pdf.

Henning E, Van Rensburg W, Smit B. Finding Your Way in Qualitative Research. Pretoria: Van Schaik Publishers; 2004.

Holloway A. Disaster risk reduction in Southern Africa. Afr Security Review. 2003;12(1):29-38.

Kameda H (2007) Networking disaster risk reduction technology and knowledge through Disaster Reduction Hyperbase (DRH). In: Proceedings of the Disaster Reduction Hyperbase (DRH) Contents Meeting, Kobe, Japan, 12-13 March. http://drh.edm.bosai.go.jp/Project/Phase2/1Documents/9_EXr.pdf.

Kuroiwa J. Peru's National Educational Program for Disaster Prevention and Mitigation (PNEPDPM). In: Training and Education for Improving Earthquake Disaster Management in Developing Countries, Report and Summary of Proceedings of the Sixth International Research and Training Seminar on Regional Development Planning for Disaster Prevention, Tsukuba, Japan, 14 December 1992, Nagoya, Japan. UNCRD Meeting Report Series, No. 57. Nagoya, Japan: United Nations Centre for Regional Development; 1993. p. 95-102. http://www.virtualref.com/uncrd/1562.htm.

Lekalakala MJ. Teachers perceptions about lesson planning to include a disaster risk reduction focus. In: Master's thesis, Disaster Management Training and Education Centre for Africa. South Africa: University of the Free State; 2011.

McMillan JH, Schumacher S. Research in Education. New York: Harper Collins: A Conceptual Introduction; 1993.

MercyCorp (2013) Supporting the Role of Schools in Disaster Risk Reduction (SRSD). http://nepal.mercycorps.org/projects/disaster-projects/srsd.php

Maxwell S, Buchanan-Smith M. Linking relief and development: introduction and overview. IDS Bulletin. 1994;25(4):1-19.

MoHA (Ministry of Home Affairs). Disaster Report of Nepal. Government of Nepal: Ministry of Home Affairs; 2003.

MoHA (Ministry of Home Affairs), UNDP (United Nations Development Programme), EC (European Comission), NSET (National Society for Earthquake Technology-Nepal). (2008). National Strategy for Disaster Risk Management in Nepal. Kathmandu: MoHA, UNDP, EC, NSET. http://www.rccdm.net/index. php?option=com_docman\&task=doc_view\&ltemid=215\&gid $=17$

MoHA (Ministry of Home Affairs). Nepal Disaster Report. In: The hardship and vulnerability. Ministry of Home Affairs, Government of Nepal and Disaster Preparedness Network-Nepal. Nepal: Jagadamba Press; 2009.
Onstada PA, Danesb SM, Hardmanc AM, Olsonc PD, Marczakc MS, Heinsd RK, et al. The road to recovery from a natural disaster: voices from the community. Community Development. 2012;3(5):566-80.

Ronan K, Crellin K, Johnston D. Correlates of hazards education for youth: a replication study. Nat Hazards. 2010;53(3):503-26.

Shiwaku K, Shaw R, Kandel RC, Shrestha SN, Dixit AM. Future perspective of school disaster education in Nepal. Disaster Prev Manage. 2007;16(4):576-87.

Tanaka K. The impact of disaster education on public preparation and mitigation for earthquakes: a cross-country comparison between Fukui, Japan and the San Francisco Bay Area, California, USA. Applied Geography. 2005;25(3):201-25.

Takeuchi Y, Mulyasari F, Shaw R. Chapter 4 Roles of Family and Community in Disaster Education. In: Shaw R, Takeuchi KSY, editors. Community, Environment and Disaster Risk Management, vol 7. UK: Emerald Group Publishing Limited; 2011. p. 77-94.

Thorne SRN. Data analysis in qualitative research. Evid Based Nurs. 2000;3(3):68-70.

UNESCO (United Nations Educational, Scientific and Cultural Organization) and UNICEF (United Nations Children's Fund). Disaster Risk Reduction in School Curricula: Case Studies from Thirty Countries. Peris: France United Nations Educational, Scientific and Cultural Organization and United Nations Children's Fund; 2012

UNISDR (United Nations International Strategy for Disaster Reduction) (2004) Hyogo Framework for Action 2005-2015. United Nations Inter-Agency Secretariat of the International Strategy for Disaster Reduction. Accessed on 25 November 2013 http://www.unisdr.org/2005/wcdr/intergover/official-doc/L-docs/Hyogoframework-for-action-english.pdf. Accessed on 25 November 2013

UNISDR (United Nations International Strategy for Disaster Reduction). Towards a Culture of Prevention: Disaster Risk Reduction Begins at School - Good Practices and Lessons Learned. Geneva: United Nations International Strategy for Disaster Reduction; 2007.

UNISDR (United Nations International Strategy for Disaster Reduction. Compilation of National Progress Reports on the Implementation of the Hyogo Framework for Action, HFA Priority 3, Core Indicator 3.2. 2011. http:// www.preventionweb.net/english/hyogo/progress/documents/hfa-reportpriority3-2(2009-2011).pdf. Accessed on May 2013.

Walshe RA, Nunn PD. Integration of Indigenous Knowledge and Disaster Risk Reduction: A Case Study from Baie Martelli, Pentecost Island, Vanuatu. Int J Disaster Risk Sci. 2012;3(4):185-94.

Yamin F, Rahman A, Huq S. Vulnerability, Adaptation and Climate Disasters: A Conceptual Overview. IDS Bulletin. 2005;36(4):1-14.

\section{Submit your manuscript to a SpringerOpen ${ }^{\circ}$ journal and benefit from:}

- Convenient online submission

- Rigorous peer review

- Immediate publication on acceptance

- Open access: articles freely available online

- High visibility within the field

- Retaining the copyright to your article

Submit your next manuscript at springeropen.com 